\title{
The Causality Issue in the Finance and Growth Nexus: Empirical Evidence from MENA Countries
}

\author{
Ghazi BOULILA ${ }^{1}$ and Mohamed TRABELSI 23
}

(October 2003)

\footnotetext{
${ }^{1}$ Faculté des Sciences Economiques et de Gestion de Tunis (FSEGT), Boulevard 7 novembre Tunis - Tunisie. Email: ghazi.boulila@planet.tn

${ }^{2}$ Institut des Hautes Etudes commerciales de Carthage (IHEC), 2016 Carthage Présidence Tunis - Tunisie, Email: mahamed.trabelsi@ihec.rnu.tn

${ }^{3}$ We wish to thank Mohamed Lahouel, Ezzedine Delhoumi, Sami Khediri and Mounir Baccouche for helpful comments and suggestions. Any remaining errors are the sole responsibility of the authors.
} 


\begin{abstract}
This paper explores the causality between financial development and economic growth in the MENA region for different periods ranging from 1960 to 2002. The empirical evidence presented in the paper, either with cointegration techniques or granger causality tests provides support, rather, to the hypothesis that causality is running from the real to the financial sector. Moreover, there is a little support to the view that finance is a leading sector in the determination of long run growth in the countries of the region. Our findings mat be attributed to (i) The strict control of the financial sector in these countries during long periods. (ii) The lateness in the implementation of financial reforms in these countries. (iii) The persisting issues in reform implementation (non-performing loans especially). (iv) The still high information and transaction costs, which prevent resources promotion and financial deepening.
\end{abstract}

Key words: Financial Development, Growth, Causality and cointegration 


\section{1- Introduction}

The relationship between financial development and economic growth has been extensively studied in the recent decades. Yet the issue is not new in development economics and may go back at least to Schumpeter (1911) who stressed the importance of financial services in promoting economic growth. Cameron (1967) has shown that in the present developed countries, the developed financial systems generally evolved during the early stages of industrialization.

Building on he work of Schumpeter (1911), Gurley and Shaw (1955), and Goldsmith (1969), McKinnon (1973) and Shaw (1973) propounded the financial "liberalization paradigm" according to it public regulation of the banking system reduces the quality and quantity of capital accumulation. The World Bank (1989) defends also this liberal views and states "efficient financial systems help to grow, partly by mobilizing additional financial resources and partly by attracting those resources to the best uses". (P.40)

More recently, the endogenous growth literature has supported that financial development (repression) has positive (negative) effects on economic growth in the steady state (Greenwood and Jovanovic (1990), Bencivenga and Smith (1991), Roubini and Sala-I-Martin (1992), Pagano (1993), King and Levine (1993b), Berthelemy and Varoudakis (1996), Greenwood and Smith (1997)).

In the other front, some economists raised their skepticism about an eventual major role of finance in economic development. Robinson (1962) for example, has suggested, in an original position, that financial development follows economic growth. Likewise, Lucas (1988) concluded, "the importance of financial markets is badly overstressed" (P.6). This conclusion is also shared by Chandavarkar (192) who has considered that finance has never been listed by the pioneers of development economics as a key development factor.

Other economists (Demetriades and Luitel (1996) has started to reject openly the amplified negative effects of financial repression policies and claimed that "intervention policies may have positive effects whenever they are able to successfully address market failure", (P318). Also, the World Bank (1993) itself modified its "extreme" liberal position by adopting a more regulated approach if public intervention would entail more equal growth that otherwise would have occurred. 
According to the theoretical literature on the topic, the views and results can be loosely grouped into two main categories du to Patrick (1966): supply leading or a demand following approach. According to the first one, financial activity is considered as a major determinant of real activity where well functioning financial systems are crucial for economic growth. For the second approach, financial activity, is taken to be a result of economic growth where growing activities require more and more funds for expansion.

\section{The empirical side of the issue}

The empirical side of the topic has been extensively treated using two main econometric approaches. Indeed, Roubini and Sala-I-Martin (1992), King and Levine (1993), Fry (1997), Levine and Zervos (1998) widely used cross-sectional techniques to support the hypothesis that financial sector development is growth enhancing and consequently financial repression policies are harmful for economic growth. In this context, Levine and Zervos (1998) concluded, " stock market liquidity and banking development are both positively and robustly correlated with contemporaneous and future rates of economic growth. (P.554).

Consequently, assuming that countries' features are similar (infrastructure, population, technologies ...etc) across countries make the statistical inference, based on cross-country analysis, far from being the optimal technique in addressing this issue. Further, the fact of dealing, in cross-sectional studies, with averages of key variables computed over quite lengthy time span may hide the variables' evolution and the way they influence one another. Moreover, a big part of developing countries proceeded to deliberate liberalization of their financial sectors aiming at developing their contribution in the growth process.

The first time series investigations in the finance and real growth nexus can be traced back to Sims (1972) who tested the causality between income and money in USA. Nevertheless, the last two decades the literature have seen a growing body of a new empirical approach in treating the causality pattern based on time series techniques (Gupta (1984), Jung (1986), Murende and Eng (1994), Demetriades and Hussein (1996), Arestis and Demetriades (1996) and Kul and Khan (1999)). In these studies, the focus is made on long run relationship between financial sector development and real growth using frameworks of bivariate and multivariate vector auto-regressive (VAR) for different country samples. The outcome was that the causality pattern varies across countries and with the success of financial liberalization policies implemented in each country and with the development level of the financial sector generally. 
The importance of the debate for developing countries comes from the fact it has important policy implications for priorities that should be given to reforms of the financial sector by public authorities. Moreover, the causality issue between financial activity and economic growth is still very far from being settled and is still unanswered. The aim of this paper is to shed more light and to look at the issue empirically. For that, we use, following Granger (1988), Sims et al. (1990) and Toda and Phillips (1993), time series techniques for a country sample of 16 MENA countries for different periods, according to data availability, ranging from 1960 to 2002 .

The choice of MENA countries is explained by the fact that there is less empirical evidence on the causal pattern between financial and real sectors of these economies where significant efficiency discrepancies are observed between the financial sectors. In addition, many countries proceeded deliberately to reform their financial sectors in order gain higher growth paths. Thus, the investigated causality issue will be useful either for economists or policy makers looking for optimal policies to found competitive financial sectors.

The results of this study are distinct from others in that we found first, less support to the hypothesis that finance is a leading sector in the growth process, second, there is a tendency for a directional causality running from real growth to the development of the financial sector. Indeed, the different tests of exogeneity either with adjustment coefficients or the lagged dynamic terms provided less support to finance as a determinant of economic growth and a strong support to the hypothesis that GDP per capita growth rate is causing the development of the financial sector. In addition, Granger causality tests based on first differenced VARs for countries where financial and economic proxies are not cointegrated; tend to corroborate the results obtained from the long-run tests.

These findings may be attributed to $(i)$ the long periods of total public control in many financial systems of the region. (ii) The lateness in the implementation of financial reforms. (iii) The persisting issues in the liberalization of financial sectors (non-performing loans especially). (iv) The persistence of high information and transaction costs in many countries.

In the remainder of the paper, we review the econometric methodology in section 2, after we present, in section 3, the different indicators that will be used in causality testing. Section 4 , presents the results obtained from the different tests either with cointegration techniques or Granger causality tests. Finally we make some concluding remarks. 


\section{2-Econometric methodology}

To test for Granger causality between two given variables $x_{1 t}$ and $x_{2 t}$, we resort to the conventional procedure, which consists to specify a bivariate vector autoregression (VAR) as follows:

$$
\left\{\begin{array}{l}
x_{1 t}=\mu_{1}+\pi_{11}(L) x_{1 t-1}+\pi_{12}(L) x_{2 t-1}+\varepsilon_{1 t} \\
x_{2 t}=\mu_{2}+\pi_{21}(L) x_{1 t-1}+\pi_{22}(L) x_{2 t-1}+\varepsilon_{2 t}
\end{array}\right.
$$

Where $\mu_{1}$ and $\mu_{2}$ are supposed constant drifts and $\pi i j(L)$ are polynomials of order $k-1$ in the lag operator $L$. According to this system, $x_{1 t}$ Granger causes $x_{2 t}$, for example, if the polynomial $\pi_{12}(L)$ is not equal to zero and this hypothesis can be tested by standard methods (example $F$-test). However, the formulation above supposes that the variables are stationary. If they are integrated $(I(1)$ processes for example), the system presented becomes misspecified (Granger (1988)) and causality tests turns to be biased.

In this case, there is a possibility of cointegration between the two variables or a long run relationship resulting from co-movements of the considered variables and a possible convergence towards a long run equilibrium state. Then in case of cointegration, the model is reparameterized in its equivalent error-correction model (ECM), (See Hendry et al (1984), Engle and Granger (1987) and Johansen (1988)):

$$
\left\{\begin{array}{l}
\Delta x_{1 t}=\mu_{1}+\gamma_{11}(L) \Delta x_{1 t-1}+\gamma_{12}(L) \Delta x_{2 t-1}+\alpha_{1}\left(\beta^{\prime} X_{t-1}\right)+\varepsilon_{1 t} \\
\Delta x_{2 t}=\mu_{2}+\gamma_{21}(L) \Delta x_{1 t-1}+\gamma_{22}(L) \Delta x_{2 t-1}+\alpha_{1}\left(\beta^{\prime} X_{t-1}\right)+\varepsilon_{2 t}
\end{array}\right.
$$

Where $\beta^{\prime} X_{t-1}$ is a linear combination of $x_{1 t}$ and $x_{2 t}$, representing the residuals from the cointegrating relationship. More succinctly, the compact from of equation (3) and (4) is rewritten as follows:

$$
\Delta X_{t}=\mu+\Gamma(L) \Delta X_{t-1}+\Pi X_{t-1}+\varepsilon_{t}
$$

Where $\Delta$ is the first difference operator, $X_{t}=\left(x_{1 t}, x_{2 t}\right)^{\prime}, \mu=\left(\mu_{1}, \mu_{2}\right)^{\prime}, \Gamma(L)=\left\{\gamma_{i j}\right\}, \Pi=\alpha \beta^{\prime}$ with $\alpha=\left(\alpha_{1}, \alpha_{2}\right)$ and $\beta=\left(\beta_{1}, \beta_{2}\right)$ and $\varepsilon_{t}$ is the vector of unexpected movements in $X_{t}, \varepsilon_{t}=\left(\varepsilon_{1 t}, \varepsilon_{2 t}\right)^{\prime}$ 
Such representation is only valid when the variables are $I(1)$ processes. Yet, if they are not cointegrated the system represented by equations (3) and (4) is not stationary and the Granger causality tests may be carried out in a first differenced VAR without the lagged level representing the error correction term (the linear combination $\beta^{\prime} X_{t-1}$ ).

If however, the variables are $I(1)$ processes but cointegrated the attention must be focused on $\Pi=\alpha \beta^{\prime}$ representing the long run parameter matrix. In this context, when we have one cointegrating vector (the rank of $\Pi$ is equal to $1, r=1$ ), $\beta$ are the parameters in the cointegrating vector and $\alpha$ are the adjustment coefficients measuring the strength of the cointegrating relationship in the error correction model (ECM). In this case we have two sources of causation of $x_{2 t}$, by $x_{1 t}$ : either through the lagged dynamic terms $\Delta x_{1 t}$ if $\gamma_{21}(L) \neq 0$, or through the lagged cointegrating vector $\beta^{\prime} X_{t-1}$, if $\alpha_{2} \neq 0$.

Indeed, the ECM describes the way the system is adjusting, in each period of time, towards its long run equilibrium state. Starting from a cointegration state, when we have, in the short run, deviations from the long run equilibrium, we will have (due to the feed back of deviations) changes in the dependant variables in order to converge their movements towards the long run Equilibrium State. The coefficients of the error correction terms, $\alpha_{1}$ and $\alpha_{2}$ represent the proportion by which the imbalance in the dependant variable is adjusted in each short-term period.

The Johanson procedure for testing cointegration focuses, therefore, on the rank of the matrix $\Pi$, which determines the number of cointegrating vectors. In a bivariate VAR framework, the number of cointegrating vectors is one and the null hypothesis is that there is no cointegrating vector and the alternative one is that we have only one cointegrating vector. To determine the rank of the matrix $\Pi$, Johanson and Juselius (1990) developed two likelihood ratio tests. The first one is the Maximum Eigenvalue (ME) test and is given by $J_{M E}=-T \ln \left(1-\lambda_{r}\right)$, where T is the number of observations and $\lambda_{r}$ is the maximal eigenvalue. The object of this test is to see whether the rank $(\Pi)=r-1$ ( $H_{0}$ hypotheses) against the alternative hypotheses $H_{a}(r-1)$. The second test is the Likelihood Ratio (LR) test is based on the trace of the stochastic matrix and given by $J_{r}=-T \Sigma \ln \left(1-\lambda_{i}\right)$ The tests in the current work are carried out using the Likelihood Ratio (LR).

This paper performs a variety of causality tests between financial development and economic growth in the MENA region. Yet, before proceeding to the implementation of the different tests, let us present, first, the different variables and their proxies used to analyze the issue. 


\section{3- Data and variables}

Three measures of financial development are used in the paper, the first one is the ratio of the liquid liabilities $\left(\mathrm{M}_{3}\right)$ to the nominal GDP (M3Y) as a financial deepening indicator. The second is the ratio of the claims to the private sector to GDP (CPY), and finally, the ratio of financial saving $\left(\mathrm{M}_{3}-\mathrm{M}_{1}\right)$ to GDP (QMY). Economic growth is measured by the real GDP per capita (y).

The first financial indicator retained is the ratio of the total assets of the financial system to nominal GDP (M3Y). The traditional proxy used to measure the extent of financial intermediation is a ratio of some broad measure of money, generally $\mathrm{M}_{2}$, to the level of nominal GDP. Nevertheless, because of the upward trend in financial innovation in the different financial systems we use a broader measure of money stock $\left(\mathrm{M}_{3}\right)$ to capture the extent of intermediation in the MENA region. The retained indicator is, therefore, the ratio of $\mathrm{M}_{3}$ to GDP (M3Y) and it is also considered in accordance with the inside money model of McKinnon (1973) where the accumulation of real money balances is a required condition for investment. An increase in this ratio may be interpreted as an improvement in financial deepening in the economy. This measure retained is also considered as less convenient with the debt-intermediation approach developed by Gurley and Shaw $(1955,1956)$ and Shaw (1973) where the accumulation of real balances is not seen as a sine-qua-non condition for investment.

The second indicator used to measure the extent of the financial activity is the ratio of the credit allocated to the private sector (CPY). This proxy is supposed to delimitate with more precision the investment financing activity and is in line with the McKinnon-Shaw inside money model where financial intermediation is responsible of the quality and quantity of capital accumulation and therefore of economic growth. The recent empirical literature (De Gregorio and Guidotti (1995) Demetriades and Hussein (1996), Levine and Zervos (1998), Rajan and Zingales (1998) and Beck, Levine and loayza (2000) is emphasizing on this indicator as one of the relevant indicators of the magnitude and the extent of financial intermediation broadly defined.

The third indicator of financial development is the ratio of financial savings to GDP (FSY), where financial savings is measured by the difference between $M_{3}$ and $M 1$, $\left[F S=M_{3}-M_{1}\right.$. The subtraction of the money stock $\left(\mathrm{M}_{1}\right)$ aims at getting the quasi-liquid assets considered as the main source of investment financing. Likewise, liquid monetary assets $\left(\mathrm{M}_{1}\right)$ are generally more destined to finance current transactions and are held, in developing countries, outside 
the banking system. Thus, a better proxy should rule out the liquid assets in circulation to be more representative of financial activity. A rising ratio of financial savings to GDP may reflect an improvement in bank deposits and / or other financial resources outside the banking sector, which are likely to be used for accumulation and growth.

For the economic growth measure, we use, in line with Demetriades and Hussein (1996) and Luintel and Khan (1999) another indicator of economic development: the real GDP per capita (y). The standard literature on the ties between economic growth and financial activity generally uses the growth rate of GDP per capita which is likely to give stationary processes.

All the variables in the data are expressed in national currency unit (Tunisian Dinar DT) and data sources are the World Development indicators of the World Bank and (2001) and the International Financial Statistics (IFS) of the International Monetary Fund (IMF).

All variables are expressed in national currencies and Data sources are the World Development Indicators of the World Bank (2001) and the international financial statistics of the IMF (2003) and statistics of the Central Bank of Tunisia for tunisian data. The time span for each variable is 1960-2002 but depending on data availability some years are dropped because of lack of data in the case of some countries.

\section{4- Empirical investigation}

Our approach consists of investigating empirically this causality between financial development and economic growth in some MENA countries (Algeria, Bahrain, Egypt, Iran, Jordan, Kuwait, Mauritania, Morocco, Oman, Qatar, Saudi Arabia, Sudan, Syria, Tunisia, Turkey and UAE). We use unit root and cointegration techniques, within a bivariate vector auto-regressive model ( $b V A R)$ for different periods spanning from 1960 to 2002, and all the proxies presented below.

In the preliminary stage, our concern is to establish the degree of integration of the variables, expressed in their natural logarithm, using the augmented Dickey-Fuller techniques. The different results of unit root tests in the level and first difference of variables are presented in table (1) (see the appendix). In each case, the null hypothesis is that the concerned variable contains a unit root against the alternative hypothesis one that the variable is stationary.

The various augmented Dickey-Fuller statistics for the whole period considered for each country, display that the first financial indicator $(M 3 Y)$ is integrated $I(1)$, exception for Oman where the variable is stationary since the unit root hypothesis is strongly rejected. For the 
claims on the private sector $(C P Y)$, the outcome is different since this variable is stationary for more countries (Jordan, Oman, Qatar, Turkey and UAE). In the case of Saudi Arabia, However, The null hypothesis is not rejected at the $5 \%$ level, which may touch on the possibility that this variable is $I(2) .{ }^{4}$ For the remaining set of countries this variable is integrated $I(1)$ except for Iran where it does not exist in the WDI data set. For the third financial indicator, namely the logarithm of the ratio of financial savings (quasi-money) to GDP ( $Q M Y)$, the hypothesis of unit root is rejected in the case of some countries ${ }^{5}$, this hypothesis is totally rejected in the case of the first difference. Outside these cases, the remaining countries this variable is integrated $I(1)$.

For the economic growth proxy, defined as the GDP per capita $(y)$, is $I(1)$ with few exceptions for Bahrain, Kuwait, Mauritania and Qatar, where the unit root hypothesis is rejected. However in the case of Saudi Arabia, the same hypothesis is not rejected at a $5 \%$ level of risk in the fist difference case and the fact that this variable is $I(2)$ is not excluded.

After achieving unit root tests, it is possible to carry out the cointegration tests between the different proxies of financial development and the economic growth to test for the existence of a stable relationship between them. The computations are based on the Johanson procedure trace statistic and. The null hypothesis is that there is no cointegrating vector and the alternative one is that we have one cointegrating vector. The Johanson tests are based on the Likelihood ratio or the so-called trace statistic. The statistics of the tests are reported in Table (2) based on a bivariate VAR with an optimal lag determined according to the Akaike Information Criteria (AIC). In fact, using this lag length the residuals in each of the VAR equations were tested for the normality distribution and the absence of serial correlation.

The tests carried out according to the Johanson procedure display less cases of cointegration as it is expected. The hypothesis of non-cointegration is rejected for the first financial indicator only for Iran. The second financial indicator, namely the ratio of claims on the private sector to nominal GDP displays also only one case of cointegration with GDP per capita: Tunisia. With the third indicator of financial activity the hypothesis of noncointegration is rejected in the case of Morocco. For the remaining countries (Algeria, Egypt, Jordan, Saudi Arabia, Sudan, Syria, Turkey and UAE) and for the different proxies of financial development, the hypothesis of the absence of cointegration can not be rejected. Such outcome rejects, in these countries, any stable relationship between GDP per capita and financial development indicators.

\footnotetext{
${ }^{4}$ When the order of integration is not clear, the cointegration tests must be interpreted with some caution.

5 The countries are Algeria, Bahrain, Jordan, Kuwait, Oman, Sudan and Syria
} 
The absence of cointegration, in these countries, may be explained by three factors. First, by the large public intervention in the in the financial sector, especially in Algeria, in a way that makes its contribution in the growth process non-optimal. Second by the relative importance of the public sector in the determination and the orientation of real output and capital allocation. Third, the absence of cointegration does not necessarily mean that this stable relationship does not exist yet it is rather non-linear or because the proposed financial indicators do not cover extensively the financial activity occurring to a large extent outside the banking system. It is also may be explained by the negative impact of banking crises and the fragility of its financial system at the beginning of the nineties (especially in Turkey).

Econometrically, the cointegration means that we have co-evolution of financial and economic indicators in these countries, which gives in the long run a cointegrating vector or a $\log$ run equilibrium state. Consequently, the short run dynamics of the variables are seen as fluctuations around this equilibrium and the ECM indicates how the system adjusts to converge to its long-run equilibrium state. The speed of adjustment, to the long run path, is indicated by the magnitudes of the coefficients of $\alpha$ vectors (i.e. $\alpha_{1}$ and $\alpha_{2}$ ). The effect of the error correction term $\beta X_{t-1}$ on economic growth depends, first, on the sign of the adjustment coefficient $\alpha_{1}$ and second, on the sign of $\beta X_{t-1}$ itself since $\beta X_{t-1}$ is a stationary process and may be positive, negative or equal to zero.

For the three countries, the adjustment coefficients $\alpha_{1}$ and $\alpha_{2}$ have opposite signs and $\alpha_{1}$ is negative and significant only in the case of Iran, which means that when the error correction term is negative, the effect on growth is positive. Nevertheless, when it is positive, real growth is affected negatively. Finally, if $\beta X_{t-1}$ is equal to zero, there is no effect on growth coming from the error correction term and only the lagged dynamic terms will have a significant effect.

The figures in the appendix display the evolution of the error correction term (ECT) in each country. The case of Iran shows that the effect on economic growth is positive for the period going from 1987 to 1998 corresponding to the post Iraqi-war period, which saw a substantial real growth. Consequently, it is not rules out the fact that the financial sector contributed significantly in the growth process after the war. The cases of Tunisia and Morocco are different since $\alpha_{1}$ is negative but not significant which excludes any effect of the financial sector on long run growth.

Which is more interesting, however, is the fact that $\alpha_{2}$ is positive and significant which constitutes a significant case of reverse causation going from economic growth to the 
development of the financial system. Indeed, the evolution of the error correction term (ECT) in Morocco shows that it is mainly positive which gives a positive effect of economic growth on financial sector development.

To check the robustness of these results, we have to see the dynamic interaction between the cointegrated variables in the long run and how each one is causing the other. To carry on this, we should test the direction of granger causality between the cointegrated indicators of financial and economic development for each country.

\section{4-1- Granger causality tests}

According to Granger (1988), if two variables are cointegrated, then we wait for Granger causation in at least one direction. The dynamic interaction between the cointegrated variables is summarized by two tests, the first one is the test of weak exogeneity and the second is a test of exogeneity of the dynamic terms.

\section{4-1-1-Tests of weak exogeneity}

A variable is said to be weakly exogenous if the error correction term is statistically insignificant in its relevant equation. In this case, the $t$-statistic is less than its critical value and consequently the variable is not adjusting to the long-run equilibrium path. Formally we have:

$$
t_{i}: \quad H_{0}: \alpha_{i}=0, i=1,2
$$

Where $\alpha_{i}$ are the adjustment coefficients in the ECM (for $\left.i=1,2\right)$ and $t_{i}$ are tests of weak exogeneity of economic growth and financial development for $i=1,2$ respectively.

\section{4-1-2-Tests of exogeneity of dynamic terms}

These tests are simply considered as Granger causality tests where the null hypothesis is that the financial development (economic growth) does not cause economic growth (financial development). Formally we have: 


$$
\begin{array}{ll}
F_{1}: & H_{0}: \gamma_{12}(L)=0 \\
F_{2}: & H_{0}: \gamma_{21}(L)=0
\end{array}
$$

Where $F_{i}$ with $i=1,2$ are the $F$-statistics of the nested hypotheses.

Table (4) reports the results of the announced tests using the Johanson procedure for the determination of the cointegrating vectors. For Iran, the evidence is in favor of bi-directional causality between real growth and financial sector development. This means that not only the financial sector is influencing economic growth but also real activity affects financial structures. Nevertheless, for Morocco and Tunisia, the causality tests are in favor of a reverse causation going from economic growth to the development of the financial sector. Indeed, the statistical significance of $F$ and $T$ statistics is likely to show that causation is going in the other. In other words, any increase in the income per capita has an influence on future ratios of financial activity.

Another result in Table (4) must be underlined and is relative to the nature of effects of real growth on financial activity. Indeed, the growth rate of GDP per capita has two effects on the indicators of financial development since $t_{2}$ and $F_{2}$ statistics are both significant in all countries (Iran, Morocco and Tunisia): the first one is coming from the lagged dynamic terms and the second from the error correction term. According to the first effect, each short-term change in the real growth rate contributes in the future change in the growth rate of financial indicators. For the second effect, given the significance of the error correction term in the second VAR equation, the economic growth is responsible for financial development through the error correction term. This means that financial activity is adjusting to the previous period disequilibrium between economic growth and financial development.

The absence of a significant positive effect of the financial sector on economic growth in Tunisia and Morocco may be explained by two main reasons. First, financial sectors in these two countries observed long periods of total public control and full government intervention in the determination and the allocation of financial resources to capital accumulation. Second, Morocco and Tunisia reformed gradually their financial sectors in 1983 and 1987 respectively and financial reforms have not yet been finished. As consequence, the expected positive effects of these financial liberalization policies on long-run growth can not be seen before the achievement of full and total liberalization of financial structures (especially the liberalization of capital accounts). 


\section{4-2- Granger causality tests based on first differenced VARs}

For the countries where financial and economic indicators are not cointegrated, causality tests carried out using first differenced VARs are shown in Table (5). The evidence presented is not far from the picture painted before and obtained from the ECMs. Indeed, in Oman, Syria and Sudan, the evidence is in Favor of a reverse causation running from the development of the financial sector to the growth of real GDP per capita with, at least, one financial indicator at $5 \%$ level. The causation turns to be bi-directional in the case of Bahrain, Qatar and UAE with the second and the third financial indicator. That is, not only the financial development appears to Granger cause real growth in the short-run, but also the same real growth seems to Granger-cause the development of financial activity too.

In Egypt, Mauritania, and Turkey, the evidence provides support, however, to the hypothesis that finance is a leading sector since the $F$-statistics are in favor of that hypothesis. Finally, for Algeria, Jordan, Kuwait and Saudi Arabia there is no evidence of a causal relationship either way with all the indicators of financial development. Such result for these countries, with the absence of any cointegration, may indicate the absence of contribution of the financial sector in the growth process.

The results obtained from first differenced VAR approach may appear, at a first sight, less consistent with those obtained from cointegration and ECM tests. The coherent picture, which emerges from Johanson cointegration and ECM tests, is that there is less evidence in favor of a long run effect of financial sector development on economic growth. Finance is found to be a leading sector, only, in the short-term link in Granger causality tests with stationary variables.

Johanson cointergation and ECM tests and Granger causality based on first differenced VARs and summarized in table (6) are suggesting also the importance of the real growth process for the development of financial structures in the MENA countries. The results show also, bi-directional relationship in some cases (Iran in the cointegration analysis and Bahrain, Qatar and UAE in Granger causality tests) between real and financial sectors.

The empirical evidence presented above has important implications for the conduct of economic and financial policies in these countries. Indeed, with an empirical evidence favoring, either a causal effect from economic growth to the financial development, or a bidirectional relationship, public effort must be oriented not only toward the promotion of real growth, but also continuing financial liberalization processes. 
In this respect, development strategies must take into account that the development of the financial sector is still depending on performances in terms of real growth. Nevertheless, such dependence must encourage policy makers to fasten financial reforms in order to increase the efficiency of financial systems and to transform them, later, in an appropriate and strategic determinant of economic growth in these countries.

\section{5- conclusion}

In this paper, we examined empirically the causality issue between financial development and economic growth in a bivariate VAR structure for a sample covering some MENA countries and different periods ranging from 1960 to 2002 .

With Johanson cointegration analysis, we found less support to the hypothesis that finance is a leading sector in growth processes. In other words, the financial sector does not seem to affect positively the long-run growth. The empirical results display also strong evidence in favor of causality running from growth of GDP per capita to financial development for two countries.

For countries where financial and growth proxies are not cointegrated, we carried out Granger causality tests with first differenced VARs to tackle the issue of causality in the short run. The evidence gave little support to the hypothesis that finance is a leading sector in the growth process. Moreover, for many countries we found evidence of bi-directional causality and causality from the real to the financial sector.

On balance, the tendency of the evidence is, rather, for causality running from real growth to financial structures in the MENA region and the financial sector is still far from playing a key role in development experiences. These findings are a bit different from Demetriades and Hussein (1996), Luintel and Kul (1999) and the differences may be attributed to several factors. First, the government intervention in financial systems of these countries during long periods made their contributions in the growth process non-optimal. Second, financial liberalization policies have not produced, yet, the expected positive effects on capital accumulation and economic growth. Third, to the presence of still non-resolved issues in reform implementation (non-performing loans especially) which entailed fragile financial structures to a certain extent. Fourth, the high information and transaction costs, which are likely to favor rent collection more than establishing systems of resources promotion and financial deepening. 


\section{Appendixes}

Table (1): The degree of integration of variables in levels and first differences (for the whole period relative to each country)

Null hypothesis: the variable contains a unit root

\begin{tabular}{lcccccccc} 
Country & \multicolumn{7}{c}{ Augmented Dickey-Fuller (ADF)(a) } \\
\cline { 2 - 7 } & M3Y & $C P Y$ & $Q M Y$ & $y$ & $\Delta M 3 Y$ & $\Delta C P Y$ & $\Delta Q M Y$ & $\Delta y$ \\
\hline Algeria & -2.387 & -1.332 & $-4.496 *$ & -2.045 & $-4.246 *$ & $-5.463 *$ & $-3.881 *$ & $-7.345 *$ \\
Bahrain & -3.558 & -2.235 & $-3.753 *$ & $-4.065 *$ & $-7.418^{*}$ & $-3.869 *$ & $-7.273 *$ & $-3.450 *$ \\
Egypt & 1.064 & -1.789 & -1.048 & -2.336 & $-2.672 *$ & $-6.679 *$ & $-4.584 *$ & $-3.630 *$ \\
Iran & -2.478 & - & - & -2.611 & $-3.797 *$ & - & - & $-3.434 *$ \\
Jordan & -1.741 & $-3.107 *$ & $-3.422 *$ & -3.177 & $-4.137 *$ & $-5.594 *$ & $-5.212 *$ & $-4.528 *$ \\
Kuwait & -2.735 & -1.539 & $-5.146 *$ & $-3.385 *$ & $-7.578 *$ & $-4.502 *$ & $-7.736 *$ & $-7.087 *$ \\
Mauritania & -1.419 & -1.759 & -2.079 & $-3.788 *$ & $-4.171 *$ & $-5.500 *$ & $-6.187 *$ & $-6.254 *$ \\
Morocco & -2.765 & -2.363 & -1.010 & -1.327 & $-7.149 *$ & $-6.179 *$ & $-4.607 *$ & $-4.835 *$ \\
Oman & $-5.422 *$ & $-5.903 *$ & $-5.031 *$ & -3.542 & $-5.864 *$ & $-6.670 *$ & $-5.691 *$ & $-4.664 *$ \\
Qatar & -2.837 & $-3.853 *$ & -1.579 & $-3.384 *$ & $-4.512 *$ & -2.030 & $-4.903 *$ & $-5.297 *$ \\
Sa. Arabia & -2.547 & -2.496 & -0.935 & -2.151 & $-4.496 *$ & -3.158 & $-3.273 *$ & -2.424 \\
Sudan & 0.254 & -0.682 & $-3.035 *$ & 8.824 & $-6.146 *$ & $-5.482 *$ & $-5.733 *$ & -2.251 \\
Syria & -2.083 & -2.369 & $-4.771 *$ & -2.041 & $-3.880 *$ & $-5.783 *$ & $-5.147 *$ & $-7.846 *$ \\
Tunisia & -2.505 & -2.670 & -3.030 & -1.776 & $-7.729 *$ & $-6.361 *$ & $-4.758 *$ & $-6.577 *$ \\
Turkey & -1.115 & $-3.117 *$ & -1.115 & -2.740 & $-4.773 *$ & $-5.385 *$ & $-4.773 *$ & $-4.883 *$ \\
UAE & -1.507 & $-4.472 *$ & -1.902 & -2.005 & $-5.169 *$ & -3.507 & $-5.264 *$ & $-4.351 *$ \\
\hline
\end{tabular}

(a) The order of the lag in the Dickey-Fuller regression is the minimum number ensuring that the residuals are white noise.

(b) The different sample periods are as follows: Algeria 1964-1999, Bahrain: 1980-1998, Egypt: 1960-1999, Iran: 1974-1999, Jordan: 1975-1999, Kuwait: 1962-1999 but we dropped 1990 from the series corresponding to Iraqi invasion on Kuwait, Mauritania: 1962-1999, Morocco: 1960-1999, Oman: 19721995, Qatar: 1970-1995, Saudi Arabia: 1960-1999, Sudan: 1960-1997, Syria: 1960-1999, Tunisia: 19612002, Turkey: 1968-1999, UAE: 1973-1998.

(c) For Iran, data is unavailable for financial savings and for the claims on the private sector in World Development indicators of the World Bank (WDI 2001). However the data for Tunisia is completed for the remaining period 2000 to 2002 from the Financial Statistics of the Central Bank of Tunisia 2003. 
Table (2): Johanson cointegration tests

\begin{tabular}{|c|c|c|c|c|c|c|c|}
\hline \multirow{3}{*}{ Countries } & \multicolumn{7}{|c|}{ Null hypothesis $r=0$, alternative hypothesis $r=1$} \\
\hline & \multicolumn{7}{|c|}{ Trace Statistic $J_{r}=-T \sum \ln \left(1-\lambda_{i}\right)$} \\
\hline & M3Y and $y$ & $k$ & $C P Y$ and $y$ & 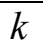 & $Q M Y$ and $y$ & $k$ & $n$ \\
\hline $\begin{array}{c}\text { Algeria } \\
1964-1999\end{array}$ & 9.615 & 4 & 8.166 & 2 & - & - & 35 \\
\hline $\begin{array}{c}\text { Egypt } \\
1960-1999\end{array}$ & 6.211 & 2 & 14.202 & 4 & 13.579 & 2 & 39 \\
\hline $\begin{array}{c}\text { Iran } \\
1974-1999\end{array}$ & $26.589 *$ & 2 & - & - & - & - & 25 \\
\hline $\begin{array}{c}\text { Jordan } \\
1960-1999\end{array}$ & 17.849 & 2 & - & - & - & - & 39 \\
\hline $\begin{array}{c}\text { Morocco } \\
1960-1999\end{array}$ & 19.821 & 4 & 10.805 & 3 & $30.988 *$ & 4 & 39 \\
\hline $\begin{array}{c}\text { Saudi Arabia } \\
1960-1999\end{array}$ & 25.159 & 4 & 18.391 & 3 & 20.693 & 4 & 39 \\
\hline $\begin{array}{c}\text { Sudan } \\
1960-1997\end{array}$ & 13.063 & 2 & 7.977 & 2 & - & - & 37 \\
\hline $\begin{array}{c}\text { Syria } \\
1960-1999\end{array}$ & 13.350 & 2 & 24.227 & 2 & - & - & 39 \\
\hline $\begin{array}{c}\text { Tunisia } \\
1961-2002\end{array}$ & 14.747 & 4 & $26.667 *$ & 4 & 13.955 & 4 & 41 \\
\hline $\begin{array}{c}\text { Turkey } \\
1968-1999\end{array}$ & 7.112 & 2 & - & - & 9.003 & 2 & 31 \\
\hline $\begin{array}{c}\text { UAE } \\
1973-1998\end{array}$ & 7.482 & 2 & - & - & 6.768 & 2 & 25 \\
\hline
\end{tabular}

(a) $r$ is the number of cointregrating vectors.

(b) $k$ refers to the number of lags used.

(c) The presence of * indicates the presence of cointegration between the variables at $5 \%$ significance level. 
Table (3): The adjustment coefficients and the error correction term

\begin{tabular}{cccc}
\hline \multirow{2}{*}{ Countries } & \multicolumn{2}{c}{ The adjustment } \\
& \multicolumn{2}{c}{ coefficients: vector } & The error correction term $\beta X_{t-1}$ \\
\cline { 2 - 3 } & $\alpha_{1}{ }^{(a)}$ & $\alpha_{2}$ & $\beta X_{t-1}=y_{t-1}-\beta_{l}(\mathrm{M} 3 \mathrm{Y})_{\mathrm{t}-1}-\beta_{2}$ \\
\hline Iran & -0.489 & 0.858 & $y_{t-1}+0.324(M 3 Y)_{\mathrm{t}-1}-8.585$ \\
$(M 3 Y)$ & $(-3.699)$ & $(3.807)$ & $(4.395)$ \\
Morocco & -0.329 & 3.743 & $y_{t-1}-0.177(Q M Y)_{\mathrm{t}-1}-0.006 t-6.418$ \\
$($ QMY $)$ & $(-1.180)$ & $(4.291)$ & $(-8.070) \quad(-3.228)$ \\
Tunisia & -0.035 & 0.806 & $y_{t-1}-1.256(C P Y)_{\mathrm{t}-1}-2.428$ \\
$(C P Y)$ & $(-0.346)$ & $(4.881)$ & $(-24.880)$ \\
\hline
\end{tabular}

(a) The numbers in parentheses are $t$-statistics.

Table (4): Results of Granger causality tests according to the Johanson procedure

\begin{tabular}{|c|c|c|c|c|c|c|}
\hline \multirow{4}{*}{ Countries } & \multicolumn{4}{|c|}{ Null Hypothesis } & \multirow{4}{*}{$n$} & \multirow{4}{*}{$k$} \\
\hline & \multicolumn{4}{|c|}{ Granger Causality between M3Y and y } & & \\
\hline & \multicolumn{2}{|c|}{ M3Y Does not Granger-Cause y } & \multicolumn{2}{|c|}{$y$ Does not Granger-Cause M3Y } & & \\
\hline & $t_{1}: \alpha_{1}=0$ & $F_{1}: \gamma_{12}(L)=0$ & $t_{2}: \alpha_{2}=0$ & $F_{2}: \gamma_{2 l}(L)=0$ & & \\
\hline $\begin{array}{c}\text { Iran } \\
1974-1999\end{array}$ & $3.699 *$ & 2.623 & $3.607 *$ & $6.607 *$ & 23 & 2 \\
\hline
\end{tabular}

Granger Causality between CPY and $y$

\begin{tabular}{ccccccc}
\hline $\begin{array}{c}\text { Tunisia } \\
1961-2002\end{array}$ & 0.346 & 0.308 & $4.881 *$ & $3.838 *$ & 37 & 4 \\
\hline
\end{tabular}

Granger Causality between $Q M Y$ and $y$

\begin{tabular}{ccccccc}
\hline $\begin{array}{c}\text { Morocco } \\
1960-1999\end{array}$ & 1.180 & 1.791 & $4.291 *$ & $3.461^{*}$ & 36 & 4 \\
\hline
\end{tabular}

The asterisk indicates significance at $10 \%$ level at least.

$k$ is the number of lags in the ECM.

$n$ is the number of observations. 
Table (5): Causality tests based on first differenced bVAR framework ${ }^{(a)}$,

\begin{tabular}{|c|c|c|c|}
\hline \multirow[b]{2}{*}{ Countries } & \multirow[b]{2}{*}{ Variables } & \multicolumn{2}{|c|}{ Null Hypothesis ${ }^{(b)}$} \\
\hline & & $\begin{array}{c}\text { FD } \neq>\text { Growth } \\
\gamma_{12}(L)=0 \\
F(k, n)\end{array}$ & $\begin{array}{c}\text { Growth } \neq>\text { FD } \\
\gamma_{21}(L)=0 \\
F(k, n)\end{array}$ \\
\hline \multirow{3}{*}{$\begin{array}{c}\text { Algeria } \\
1964-1999\end{array}$} & $(y, M 3 Y)$ & 1.631 & 0.277 \\
\hline & $(y, C P Y)$ & 1.807 & 0.352 \\
\hline & $(y, Q M Y)$ & 2.687 & 0.970 \\
\hline \multirow{3}{*}{$\begin{array}{c}\text { Bahrain } \\
1980-1998\end{array}$} & $(y, M 3 Y)$ & $3.936 *$ & $5.133 *$ \\
\hline & $(y, C P Y)$ & 0.679 & 0.093 \\
\hline & $(y, Q M Y)$ & 1.233 & $4.071 *$ \\
\hline \multirow{3}{*}{$\begin{array}{c}\text { Egypt } \\
1960-1999\end{array}$} & $(y, M 3 Y)$ & $4.119 *$ & 1.505 \\
\hline & $(y, C P Y)$ & 2.409 & 1.075 \\
\hline & $(y, Q M Y)$ & $4.128 *$ & 0.858 \\
\hline \multirow{3}{*}{$\begin{array}{c}\text { Jordan } \\
1975-1999\end{array}$} & $(y, M 3 Y)$ & 0.089 & 0.519 \\
\hline & $(y, C P Y)$ & 1.407 & 0.093 \\
\hline & $(y, Q M Y)$ & 0.825 & 0.713 \\
\hline \multirow{3}{*}{$\begin{array}{c}\text { Kuwait } \\
1962-1999\end{array}$} & $(y, M 3 Y)$ & 0.322 & 0.360 \\
\hline & $(y, C P Y)$ & 0.415 & 1.614 \\
\hline & $(y, Q M Y)$ & 0.456 & 0.171 \\
\hline \multirow{3}{*}{$\begin{array}{l}\text { Mauritania } \\
1962-1999\end{array}$} & $(y, M 3 Y)$ & $3.045 *$ & 1.836 \\
\hline & $(y, C P Y)$ & $3.024 *$ & 0.418 \\
\hline & $(y, Q M Y)$ & 0.829 & 2.188 \\
\hline \multirow{3}{*}{$\begin{array}{c}\text { Morocco } \\
1960-1999\end{array}$} & $(y, M 3 Y)$ & 1.052 & 1.153 \\
\hline & $(y, C P Y)$ & $2.922 *$ & 0.162 \\
\hline & $(y, Q M Y)$ & The $v$ & ated \\
\hline
\end{tabular}

(a) The order of the lag is determined using the Akaike information criterion (AIC) on the unrestricted bVAR.

(b) All estimates are achieved using first differences of integrated variables.

(c) The asterisk indicates that the Fischer statistics are significant at the 5\% level. 
Table (5)(continued): Causality tests based on first differenced bVAR framework ${ }^{(a)}$,

\begin{tabular}{|c|c|c|c|}
\hline \multirow{3}{*}{ Countries } & \multirow{3}{*}{ Variables } & \multicolumn{2}{|c|}{ Null Hypothesis ${ }^{(b)}$} \\
\hline & & $\begin{array}{c}\text { FD } \neq>\text { Growth } \\
\gamma_{12}(L)=0\end{array}$ & $\begin{array}{c}\text { Growth } \neq>\text { FD } \\
\gamma_{2 l}(L)=0\end{array}$ \\
\hline & & $F(k, n)$ & $F(k, n)$ \\
\hline \multirow{3}{*}{$\begin{array}{c}\text { Oman } \\
1972-1995\end{array}$} & $(y, M 3 Y)$ & 0.539 & $3.253 *$ \\
\hline & $(y, C P Y)$ & 1.471 & $4.656 *$ \\
\hline & $(y, Q M Y)$ & 0.215 & $3.599 *$ \\
\hline \multirow{3}{*}{$\begin{array}{c}\text { Qatar } \\
1970-1995\end{array}$} & $(y, M 3 Y)$ & $4.379 *$ & 2.600 \\
\hline & $(y, C P Y)$ & $5.579 *$ & $3.626 *$ \\
\hline & $(y, Q M Y)$ & 0.856 & 2.180 \\
\hline \multirow{3}{*}{$\begin{array}{c}\text { Saudi Arabia } \\
1960-1999\end{array}$} & $(y, M 3 Y)$ & 0.618 & 2.231 \\
\hline & $(y, C P Y)$ & 0.114 & 0.154 \\
\hline & $(y, Q M Y)$ & 0.638 & 1.753 \\
\hline \multirow{3}{*}{$\begin{array}{c}\text { Sudan } \\
1960-1997\end{array}$} & $(y, M 3 Y)$ & 0.456 & $8.102 *$ \\
\hline & $(y, C P Y)$ & 0.058 & 1.260 \\
\hline & $(y, Q M Y)$ & 0.709 & 0.087 \\
\hline \multirow{3}{*}{$\begin{array}{c}\text { Syria } \\
1960-1999\end{array}$} & $(y, M 3 Y)$ & 2.600 & 2.143 \\
\hline & $(y, C P Y)$ & 0.498 & $3.078 *$ \\
\hline & $(y, Q M Y)$ & 0.096 & $3.430 *$ \\
\hline \multirow{3}{*}{$\begin{array}{c}\text { Tunisia } \\
1961-2002\end{array}$} & $(y, M 3 Y)$ & 0.266 & 2.388 \\
\hline & $(y, C P Y)$ & \multicolumn{2}{|c|}{ The variables are cointegrated } \\
\hline & $(y, Q M Y)$ & 0.328 & 2.580 \\
\hline \multirow{3}{*}{$\begin{array}{c}\text { Turkey } \\
1968-1999\end{array}$} & $(y, M 3 Y)$ & 1.602 & 0.892 \\
\hline & $(y, C P Y)$ & $2.999 *$ & 0.696 \\
\hline & $(y, Q M Y)$ & 0.066 & 1.864 \\
\hline \multirow{3}{*}{$\begin{array}{l}\text { UAE } \\
973-1998\end{array}$} & $(y, M 3 Y)$ & $12.930 *$ & 2.738 \\
\hline & $(y, C P Y)$ & 0.412 & 0.656 \\
\hline & $(y, Q M Y)$ & $11.945 *$ & $4.119 *$ \\
\hline
\end{tabular}


Table (6): Summary of the Results with Cointegration and Granger Causality tests

\begin{tabular}{|c|c|c|c|c|c|c|c|c|c|}
\hline \multirow{2}{*}{ Country } & \multicolumn{3}{|c|}{ Tests with $M 3 Y$} & \multicolumn{3}{|c|}{ Tests with $C P Y$} & \multicolumn{3}{|c|}{ Tests with $Q M Y$} \\
\hline & $\begin{array}{l}\text { Cointe } \\
\text { gration }\end{array}$ & $\begin{array}{l}\mathrm{FD}=> \\
\text { Growth }\end{array}$ & $\begin{array}{l}\text { Growth } \\
=>\mathrm{FD}\end{array}$ & $\begin{array}{l}\text { Cointe } \\
\text { gration }\end{array}$ & $\begin{array}{l}\mathrm{FD}=> \\
\text { Growth }\end{array}$ & $\begin{array}{l}\text { Growth } \\
\Rightarrow>\mathrm{FD}\end{array}$ & $\begin{array}{l}\text { Cointe } \\
\text { gration }\end{array}$ & $\begin{array}{l}\mathrm{FD}=> \\
\text { Growth }\end{array}$ & $\begin{array}{l}\text { Growth } \\
\Rightarrow>\mathrm{FD}\end{array}$ \\
\hline Algeria & No & No & No & No & No & No & No & No & No \\
\hline Bahrain & No & Yes & Yes & No & No & No & No & No & Yes \\
\hline Egypt & No & Yes & No & No & No & No & No & Yes & No \\
\hline Iran & Yes & - & - & - & - & - & - & - & - \\
\hline Jordan & No & No & No & No & No & No & No & No & No \\
\hline Kuwait & No & No & No & No & No & No & No & No & No \\
\hline Mauritania & No & Yes & No & No & Yes & No & No & No & No \\
\hline Morocco & No & No & No & No & Yes & No & Yes & - & - \\
\hline Oman & No & No & Yes & No & No & Yes & No & No & Yes \\
\hline Qatar & No & Yes & No & No & Yes & Yes & No & No & No \\
\hline Sa. Arabia & No & No & No & No & No & No & No & No & No \\
\hline Sudan & No & No & Yes & No & No & No & No & No & No \\
\hline Syria & No & No & No & No & No & Yes & No & No & Yes \\
\hline Tunisia & No & No & No & Yes & - & - & No & No & No \\
\hline Turkey & No & No & No & No & Yes & No & No & No & No \\
\hline UAE & No & Yes & No & No & No & No & No & Yes & Yes \\
\hline
\end{tabular}


Figure (1): The evolution of the error correction term (ECT) in Iran, Morocco and Tunisia
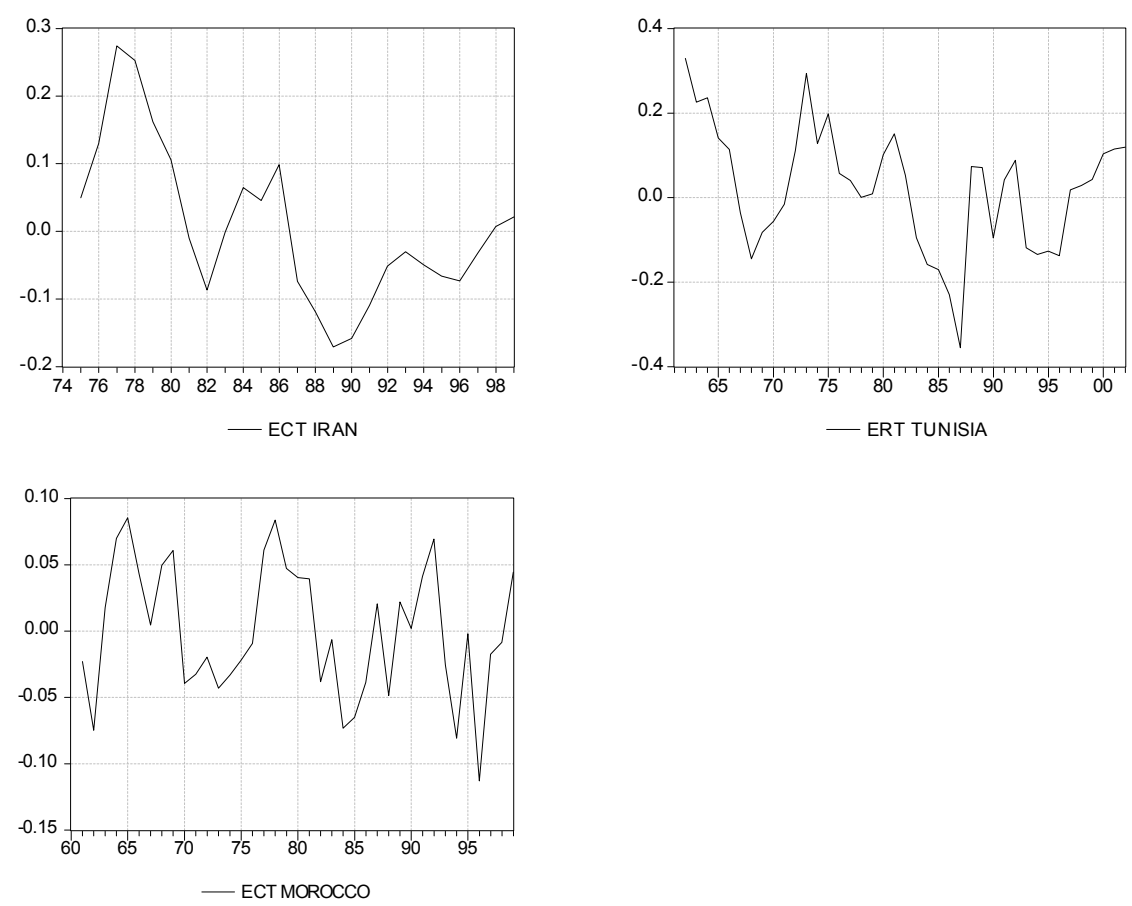


\section{REFERENCES}

Arestis, Philip and Demetriades, Panicos, (1997) " Financial Development and Economic Growth: Assessing the Evidence ", The Economic Journal, 107(May): 783-799.

Bagehot, Walter, (1873), Lombard Street, 1962 ed. (Richard D. Irwin, Homewood, IL)

Thorsten Beck, Ross Levine and Norman Loayza, (2000), " Finance and the Sources of Growth", Journal of financial Economics, (58): 261-300.

Bencivenga, Valerie et Smith, Bruce, (1991), " Financial Intermediation and Endogenous Growth ", Review of economic Studies, 58:195-209.

Banque Centrale de Tunisie, Statistiques Financières, 2002.

Cameron, Rondo (1967), Banking in Early Stages of Industrialization, Oxford University Press, New York.

Chandavarkar, Anand,(1992), " Of Finance and Development : Negelected and Unsettled Questions", World Development, 20(Jan.): 133-142.

De Gregorio, Jose and Guidotti, Pablo (1995), " Financial Development and Economic Growth ", World Development, 23(Mar.): 433 - 438.

Demetriades, Panicos, and Khaled A. Hussein, (1996), " Does Financial Development Cause Economic Growth? Time-series Evidence from 16 Countries', Journal of Development Economics, 51: 387-411.

Demetriades, Panicos, and Luintel, K, (1996), " Financial Development, Economic Growth and Banking Sector Controls: Evidence From India ', The Economic Journal, 106: 359-374.

Engle, Robert and Clive W.J. Granger, (1987), " Cointegration and Error-correction: Representation, Estimation and Testing" Econometrica(55): 251-276.

Fry, Maxwell, J., (1988),' Money, Interest and Banking in Economic Development', The John Hopkins University Press.

Fry, Maxwell, J.,(1997), " In Defence of Financial Liberalization ', The Economic Journal, 107(May): 754-770.

Goldsmith, Raymond, (1969), Financial structure and Development, New Haven, CT: Yale University Press.

Granger, C. W. J, (1988) ' Some Recent Developments in a Concept of Causality ', Journal of Econometrics, 39: 199-211.

Greenwood, Jeremy and Smith, Bruce (1997),' Financial Markets in Development, and the Development of Financial Markets ', Journal of Economic Dynamic and Control, 21: 145181.

Gurley, John G. and Shaw, Edward S. (1955), ' Financial Aspects of Economic Development ", American Economic Review, 45(Sept): 515-538.

Gupta, Kanhaya L., (1984), Finance and Economic Growth in Developing Countries, London: Croom Helm 
International Monetary Fund Data Set, 2003.

Hendry, David, A.R. Pagan and J.D Sargan, (1984), Dynamic Specification, in Zvi Chriliches and Michael D. Intriligator (eds), Handbook of Econometrics, Amsterdam: North Holland.

Johanson, S. (1988) "'Statistical Analysis of Co-integrating Vectors " Journal of Economic Dynamic and Control, 12: 231-254.

Johanson, S. and K. Joselius (1990) ' Maximum Likelihood Estimation and Inference on Cointegration with Application to the Demand for Money "' Oxford Bulletin of Economics and Statistics, 52: 169-210.

Jung, W. S (1986) " Financial Development and Economic Growth " Economic Development and Cultural Change, 34: 336-346.

King, Robert G. and Levine, Ross. (1993a), ' Finance and Growth: Shumpeter Might be Right ', Quarterly Journal of Economics, 108(Aug): 717-737.

King, Robert G. and Levine, Ross. (1993b),' Finance, Entrepreneurship and Growth: Theory and Growth ', Journal of Monetary Economics, 32(Dec): 513-542.

Kul B. Luintel and Moshahid Khan, (1999), ', A Quantitative Reassessment of the Financegrowth Nexus: Evidence from a Multivariate VAR ", Journal of Development Economics,

Levine, Ross (1997), ' Financial Development and Economic Growth: Views and Agenda ", Journal of Economic Literature, 25(June): 688-726.

Levine, Ross and Zervos, Sara (1998) " Stock Markets, Banks and Economic Growth ", American Economic Review, Volume 8: 537-558.

Lucas, Robert E., Jr.(1988), " On the Mechanics of Economic Development ", Journal of Monetary Economics, 22(July): 3-42.

McKinnon, Ronald I., (1973), " Money and Capital in Economic Development ', Washington DC: Brookings Institution.

McKinnon, Ronald I.(1988), " Financial Liberalization in Retrospect: Interest Rate Policies in LDC's " In the State of Development Economics (Ed G. Ranis and T. P. Stulz). Oxford: Basil Blackwell. P: 386-415.

Murinde, V. et F. Eng (1994), ' Financial Development and Economic Growth in Singapore: Demand-following of Supply-leading ? ', Applied Financial Economics, 4, 391-404.

Nsouli, Saleh; Eken, Sena; Duran, Paul; Bell, Gerwin and Yücelik, Zühtü (1993), '’ The Path to Convertibility', IMF Occasional Paper, n 109, December.

Osterwald-Lenum, M., (1992), " A note with Quintiles of Asymptotic Distribution of the ML Co-integration Rank statistics ', Oxford Bulletin of Economics and Statistics, 54: 461-472.

Pagano, Marco, (1993), ' Financial Markets and Growth: An Overview ', European Economic Review, 37(Apr): 613-622.

Patrick, H. (1966) " Financial Development and Economic Growth in Underdeveloped Countries " Economic Development and Cultural Change, 14: 174-189.

Quah, D, (1993) " Empirical Cross Dynamics in Economic Growth "European Economic Review, 37, 426-434. 
Robinson, J., (1952), The Rate of Interest and Other Essays, Macmillan, London.

Schumpeter, Joseph A.,(1912), Theorie der Wirtschaftlichen Entwicklung ( The Theory of Economic Development ). Leipzig: Dunker\& Humblot, Translated by Redvers Opie, Cambridge, MA: Harvard University Press, 1934.

Shaw, E., (1973), ' Financial Deepening in Economic Development ", New York: Oxford University Press.

Sims, Christopher A., (1972)," Money Income and Causality", American Economic Review, (62): 540-552.

Sims, C.A., J.H. Stock and M.W.Watson, (1990), " Inference in Linear Time Series Models With Some Unit Roots "'Econometrica, 58: 113-144.

Singh, Ajit and Bruce A. Weiss, " Emerging Stock Markets, Portfolio Capital Flows and Long-Term Economic Growth: Micro and Macroeconomic perspectives" World Development, 26 (1998): 607-22.

Toda, H. and P.C.B. Phillips (1993), ", Vector Auto-regressions and Causality ", Econometrica, 61:1367-1393.

World Bank (1989), World Development Report (1989), New York: Oxford University Press for the World Bank.

World Bank (1993), East Asian Miracle: Economic Growth and Public Policy, Oxford Oxford, University Press for the World Bank. 
